\title{
Review Essay: \\ Street Life in Early Modern Europe*
}

\author{
by FABRIZIO NEVOLA
}

E arly modern streets have only recently emerged as a subject area for research, driven by a growing interest in urban space and how it is fashioned through social interactions. It is an indication of the extent to which spatial concerns and material culture have become key concepts in contemporary ways of understanding and interpreting the past that the exhibition and accompanying catalogue for the British Museum's contribution to the 2012 Cultural Olympiad considered Shakespeare's theater in these terms. Shakespeare: Staging the World was the result of successful collaboration between leading Shakespeare scholar Jonathan Bate, and Dora Thornton, curator for Renaissance Europe at the British Museum. The book, like the exhibition, deftly weaves together topography and chronology to reveal the key spaces of Shakespeare's production London as the site of performance, but Rome and Venice as standing for London too - and the material artifacts that anchor the narrative of the plays to those places.

While offering a clear interpretative frame for Shakespeare's works, Bate and Thornton use the full armory of material culture to underpin their discussion and to articulate the sequence of the exhibition layout and the book chapters. Autograph manuscripts, early printed works, portraits of patrons, and tapestry maps of Arden and Warwickshire constitute a core framework. However, it is the tangential everyday objects that really shed new light on the period, and add texture and meaning to this contextualized view of early modern London's theatergoing world. Thus, while the association of the writing of Julius Caesar to the classical triumph prepared in London in honor of James I on 15 March 1604 informs a chapter on the adoption of classical culture and the complex interrelation woven between past and present in that history play, that proximity is made

"As an Italianist, achieving a European reach for this review would not have been possible without the facilities and staff of the Bodleian Library (Oxford) and the suggestions of a number of friends and colleagues, including Peter Arnade, Felipe Pereda, Deana Rankin, Gerrit Schenk, and Charles Zika. Thanks also to David Rosenthal for his helpful comments. Omissions and blind spots are all my own, however. 
tangible through discussion of such objects as the statute-cap. As Neil MacGregor has shown in Shakespeare's Restless World, these caps are referred to directly by Shakespeare more than once as a shorthand to describe plebeian crowds, and were mandatory holiday wear for males over six; his description of a few rare surviving examples brings to life a crowd across the centuries. Similar strategies are employed to discuss such varied aspects of everyday life as the smoking of clay pipes at the theater; duels and knife violence in the streets of the city; and gambling, bearbaiting, and street food in the theater district south of the Thames in Southwark.

As the Swiss traveler Thomas Platter noted in 1599, "the English pass their time, learning at the play what is happening abroad: indeed men and womenfolk visit such places [theaters] without scruple, since the English for the most part do not travel much." ${ }^{1}$ Platter was struck by various aspects of London life, including the theater, but also such activities as animal fighting, gambling, and drinking, as well as the policing of streets. Bate and Thornton show how antiquity, current affairs, the interpretation of English history, religious politics, and New World discoveries were all topics ripe for dramatic entertainment, but also reveal how the plays and the scant surviving material traces of the theatergoers themselves permit us privileged views into this rich social world of the entertainment district of early modern London. In so doing they bring together material artifacts that help reassemble aspects of the everyday street life of the city.

Until recently, streets, both as a unit of urban space and as a public environment for social interaction, have not commanded much attention from scholars. Urban and architectural historian Spiro Kostof dedicates an important chapter in The City Assembled to the street as both "container and content," in which he notes that a history of streets and the interrelation of people and place have yet to be written. Echoing Joseph Rykwert's comment that a "street is human movement institutionalized," Kostof examines how human use shapes urban form as much as formal design strategies that impose grand set-pieces on the urban fabric; this binary process sets the agenda for considering the public realm historically. The Festschrift volume in honor of Kostof edited by Yeynep Çelik, Diane Favro, and Richard Ingersoll, Streets: Critical Perspectives on Public Space, brings together a number of essays on streets through different periods and cultures. The collection effectively illustrates how the street can be considered as a unit of urban form, best understood through interdisciplinary analysis that brings to bear a variety of factors, ranging from political to economic, from

${ }^{1}$ Bate and Thornton, 49.

${ }^{2}$ Rykwert, 15 . 
social to aesthetic, and often including a consideration of the relationship of the ritual functions of the built environment to the people that inhabit it. Nevertheless, it is only quite recently that streets and life in streets have begun to attract dedicated research from historians, as in Cultural History of Early Modern European Streets, a recent collection edited by Riitta Laitinen and Thomas Cohen. The collection specifically addresses the cultural history of early modern European streets, considering them as a material expression of the dynamics that regulate the boundaries and relationships between public and private, and indeed seeing the street as a useful unit for questioning the very concept of private in favor of a more nuanced gradation between public and domestic experiences of space.

The ways that public spaces in cities were used have come to command a growing interest among historians of the Renaissance and early modern period, and new fields for research have emerged from this attention as a result. Following on the study of ritual uses of urban spaces in staged processional events by Edward Muir and others, a wave of interest has been directed at the more mundane, or everyday, practices of urban life in the past. Such a shift toward the analysis of everyday uses of urban space has been influenced by works on ritual and social drama, such as those of Arnold van Gennep and Victor Turner, and work on the social production of space and spatial practices by Michel de Certeau and Henri Lefebvre. Combined to varying degrees, this concern for social interactions located in their physical contexts has contributed to defining what the cultural geographer Denis Cosgrove has described as a "spatial turn" (and Sigrid Weigel has termed a "topographical turn") in historical research. Within such a methodological framework, the street emerges as a prime performative urban space, where individual and collective actions and behaviors inscribe spaces with meaning that accumulates over time. Some years ago now, Richard Trexler commented that "social spaces are central to the formation, expression and modification of individual and group identities." 3 Streets are just such a social space, and street life is everyday and ritualized, its meanings deposited on the urban fabric through repetitive usage as well as exceptional breaks from the norm.

A vast and growing literature - exemplified in the two-volume Europa Triumphans project edited by Ronnie Mulryne, Helen Watanabe-O'Kelly, and Margaret Shewring - considers city streets as the stage for processions and other forms of urban ritual, such as triumphal entries, religious festivals, and events marking the lifecycle of individuals (marriage, funeral, etc.).

${ }^{3}$ Trexler, 1985, 4. 
Analysis and interpretation of such ceremonial events has tended to follow the leads of Trexler and Muir, whose landmark studies of Florence and Venice, respectively, have provided a benchmark for studies throughout Europe. For example, the ceremonial spaces and uses of streets in cities in Spain have been analyzed to reveal the symbolic value of ritual routes: Susan Verdi Webster focuses on the Holy Week processions of Seville and the adaptation of such local practices associated with the city patron in Art and Ritual in Golden-Age Spain, and María José del Río Barredo's Madrid, urbs regia examines the adoption of the Señora de Atocha for the propagandistic purposes of the monarchy in Madrid. Moshe Sluhovsky has revealed a similar process at work in the cult of St. Geneviève in Paris, which under the Bourbon monarchy was refashioned so that the civic ritual was assigned new meaning, with the saint as a privileged protectress of the royal family. As Muir has shown, the way in which urban processions of varied sorts - be they regularly occurring religious ceremonies or extraordinary events such as the entries of monarchs - often utilized the same routes has been seen as a sign of unified urban image projected ephemerally by ceremonies and in permanent form by the built fabric along such routes. As Peter Arnade and Elodie Lecuppre Desjardin have each argued with respect to Burgundian Flanders, urban rituals were a key way in which court-city relations were encoded, and in which fealty was declared and made manifest. Equally, however, such urban rituals and the unity they enshrined have been understood to reveal the frictions and fractures between communities and groups within the city as, for example, Charles Zika's "Hosts, Processions and Pilgrimages," Miri Rubin's Corpus Christi, and Franz-Josef Arlinghaus's "The Myth of Urban Unity" have shown for religious rituals in Germany.

Outside such ritual use, though, discussions of streets have tended to be divided between the analysis of their built characteristics by architectural historians, and the life occurring on and around them by predominantly social or urban historians. While Laitinen and Cohen state the intention of underlining the "nature of the street as an urban material entity," the collection engages only partially with the visual form of the streets that its articles consider, a criticism that can also be leveled at Leif Jerram's recent book on twentieth-century street life. The title of Rudolph Bell's recent book on Rome - Street Life in Renaissance Rome: A Brief History with Documents - suggests this volume might engage more fully with the material environment; however, its author barely mentions the fabric of

${ }^{4}$ Laitinen and Cohen, 197. 
the city, nor really the physical experience of it by its residents. Conversely, recent studies by Stuart Blumin and Enzo Dubbini of the streetscape in seventeenth-century painting have tended to explain the genre of street views, or vedute, in terms of phenomena such as the Grand Tour and the circulation of images of modernity in the cities of Continental Europe, rather than engage specifically with the actions and behaviors represented in the genre. So too the growing scholarly attention to the emergence of increasingly accurate urban maps from the later fifteenth century - as shown, for example, in Naomi Miller's Mapping the City — has not tended to engage with an analysis of everyday use or knowledge of those urban spaces by contemporaries. Cartography at this period was not about navigation of the urban realm by everyday users, although the increasingly accurate maps of cities such as Rome, London, or Paris are an invaluable aid for the historian who wishes to put the details of social life in cities back into their contemporary settings. This review does not explore the innovations in urban mapping and the application of geographic information systems (GIS) to early modern cities, as this is the subject of a recent review by Michael Ullyot in this journal; impressive examples are Locating London's Past, which plots judicial records on John Rocque's 1746 map of the city, and Visualizing Venice, which applies historical geographic information system (HGIS) modeling of documents and archival sources to visualize change in the city over time.

Bringing together the spatial, material, and social qualities of city streets can bear rich rewards, as Diane Favro has argued and as Georgia Clarke and Fabrizio Nevola show in a new collection of articles. Studies of early modern Rome have revealed the far-from-casual meanings associated with urban space, its ownership, and the conflicts that emerged from disputes on and around public streets, as, for example, Manfredo Tafuri's "'Roma Instaurata," Joseph Connors's "Alliance and Enmity in Roman Baroque Urbanism," and Laurie Nussdorfer's "The Politics of Space in Early Modern Rome" have shown. Similarly, Hilary Ballon's interdisciplinary study of Paris demonstrates how new streets (as well as squares and bridges) were harnessed and used to project a powerful image of the French monarchy, as Martha Pollak has shown for Turin under the Dukes of Savoy. Again, however, since the subjects of such studies of urbanism are predominantly rulers, the scale and nature of the interventions discussed tend to privilege ritual use of streets as an expression of large-scale patronage and propaganda, quite distinct from the more everyday city functions of resident communities and groups.

A useful contrast is offered by those studies that focus on nonelite functions of urban space and streets, and it is here that truly innovative 
subjects for research have emerged. The "fertile spaces" of street life in early modern Europe, described in an article by Peter Arnade, Martha C. Howell, and Walter Simons, are placed on the boundaries between public and domestic space, and were embodied by those individuals and groups whose existence was defined by an interstitial condition. Recent studies have turned to those physical spaces that mediate between public realm and domestic space, and the social interactions that are encouraged by those liminal situations. Among these, special attention has been afforded to shops and shopping, an activity that, as Donatella Calabi and Evelyn Welch have each demonstrated, was largely conducted in the public space of streets and squares. While the history of shopping has a growing bibliography of its own, specific sorts of shops have attracted scholarly attention as semipublic places, where particular forms of dynamic social interaction were facilitated in the city. In a collection edited by Sandra Cavallo and David Gentilcore and in a recent book by James Shaw and Evelyn Welch, both focusing south of the Alps, special attention has been given to pharmacies as places where medical information as well as neighborhood gossip circulated freely. So too the tavern has been the object of numerous studies, such as those by Beat Kümin, Ann Tlusty, and Thomas Brennan, which have considered the varied nature of these social spaces, especially north of the Alps. Such studies show how taverns were important junctions in everyday social interaction, communication, and identity formation for men of all classes, as well as hubs of community for more specific, usually lower-class, groups. They were also contested spaces, and spaces around which broader conflicts turned, due to both a real and an imagined association with everyday violence, prostitution, sodomy, gambling, and sometimes with political or religious subversion.

The tavern and pharmacy were socially and symbolically significant places, and ones that provide a physical expression and location to social practices and behaviors that are central to defining concepts of street life. To this day, the word street is often a negative qualifier in conjunction with other terms, and it is noticeable that similar judgments pertain when applied to the historical past: crime and deviant behavior are commonly associated with streets and public spaces in the city. One obvious example that has received attention across most European contexts is prostitution, although the spatial dimensions of this profession have only been subjected to scrutiny in more recent scholarship, as in the work of Diane Ghirardo on Ferrara, David Mengel on Prague, and Naomi Miller on Paris. Streets, taverns, and bathhouses were closely associated with prostitution, and the prosecution of such activity was increasingly street specific, as well as being associated predominantly with nighttime, as Frank Rexroth and Laura Gowing have 
each shown for London. A dominant theme that emerges from two recent books, by Roger Ekrich and Craig Koslofsky, on nighttime in the early modern period is nighttime's association with crime, and the opportunities that darkness offered for breaking the boundaries between public and private space. Indeed, the advent of modernity in the city was for some heralded precisely by the introduction of street lighting in the later seventeenth century, and the perceived effects that this had on reducing criminal behavior in public space.

Beyond crime, the street was a privileged site for the performance of collective and individual acts and rituals of violence and justice. We may well question Michel Foucault's famously neat break between the performative, violent justice of the Middle Ages and the subtle surveillance of the Enlightenment state, as I have done in an article on surveillance and the street; but it is nonetheless evident that the public space of cities was integral to the processes of justice in much of Europe. As Julius Ruff shows, processions regularly formed around the routes leading those condemned to capital punishment to their site of execution; and in Southern Europe, as Nicholas Terpstra has remarked, confraternities were established to orchestrate and bring succor to the condemned, while crowds gathered to watch the spectacle. Conversely, the street might be the chosen site for particular crimes such as honor killings to be meted out; in such cases, as Thomas Cohen and Guido Rebecchini have both shown, it was obviously the public nature of the space and the performative nature of the acts that made the street a favored setting. Other factors, such as neighborhood rivalries and conflicts, as well as the assertion of masculinity, could be articulated in the many ritual battles that animated the cities of the period. Here, the physical borderlines between groups - which regularly coincided with streets (just as regional boundaries so often do with watercourses) were the site for the ritual renegotiation of those borders, as Robert Davis has shown for the especially colorful fistfights that took place on the bridges of Venice between members of rival factions, or the brawls that broke out outside taverns in Germany, as documented by Ann Tlusty.

While the street may be associated with crime and violence, it has also come to be seen as an alternative locus in which to find and define the early modern public sphere, as in Bronwen Wilson and Paul Yachnin's Making Publics in Early Modern Europe and Massimo Rospocher's Beyond the Public Sphere. Filippo de Vivo's Information and Communication in Venice explores various public spaces of Venice as communication hubs, suggesting that certain sites in cities mediated and favored the transfer of information in printed and oral form. This transfer of significant information regarding public affairs is leading to a more robust mapping of a pre-Habermasian 
public sphere - referring to the identification of forms and practices of behavior equivalent to the public sphere Habermas describes but in a historical era predating that of the coffee house — as argued by both Beat Kümin and Andrew Pettegree, proposing a culture of conversation that widens the participation in political discourse. It was sites such as street corners and piazzas, as Rosa Salzberg has demonstrated, that were favored by street singers, storytellers, and news pamphleteers, fuelling the enormous diffusion of cheap print from the early sixteenth century and the sale and performance of those texts in public spaces, as the new Italian Voices research project shows.

This view of the emerging public sphere builds on the interactions that were intrinsic to the marketplace as a space of commerce and the exchange of knowledge and goods, as Carol Symes has indeed argued for medieval Arras. Logically enough, just as early modern news and its circulation was transacted through these public-space hubs, as Brendan Dooley has argued, so too such information exchange can also be traced in earlier periods to the work of heralds and town criers in the publication of laws and the prosecution of crimes that occurred at key sites such as street corners and marketplaces, as Steven Milner argues. The words of Thomas Platter cited at the outset make it clear that in England the fast-developing world of the theater also in part served as a site of exchange of news and information. Indeed, Jacobean city comedy emerged as a genre developed in direct relation to the contemporary context of London, as Heather Easterling has observed, in which productions "provided their city audiences with a decidedly less honorific parsing of the urban world than their pageantry." Moreover, works such as Middleton and Dekker's The Roaring Girl and Jonson's Bartholomew Fair turned the subject of theater to the conditions and ambiguities of the contemporary city and especially the place of women in it, as James Mardock, Jean Howard, and others have shown. Such depictions in dramatic texts are a reminder that the role of public space in asserting, challenging, and negotiating issues of gender, class, and identity is perhaps the aspect of street life that has received most attention in recent scholarly literature, as emerges from collections edited by Judith Brown with Robert Davis, and by Amanda Flather, as well as the literature review Urban Communities in Early Modern Europe by Fabrizio Nevola and David Rosenthal. As Elizabeth Cohen has recently noted, however, it is important to progress beyond the male-female, public-private dichotomy, as there remains an "unworkable gap between an ideal of protective, and

${ }^{5}$ Easterling, 6. 
constraining, enclosure and the realities of most women's lives": ${ }^{6}$ the street was a place where this "gap" plays out in practices and behaviors that warrant further study.

A final area to survey in this review is the growing attention afforded to the sensory environment of the city and its public spaces, an area rich with potential as a collection by Alexander Cowan and Jill Steward shows. A series of studies, following in part on the groundbreaking research into aural sensorium by R. Murray Schafer, have precipitated enquiries into the soundscapes of the past, as David Garrioch has indicated. Theatergoing London, and the experiential relationship of theater and city, is the subject of Bruce R. Smith's remarkable work of historical phenomenology of the sonic environment, which examines the "number of overlapping, shifting, acoustic communities, centered on different soundmarks: parish bells, the speech of different nationalities, the sounds of trades, open-air markets, the noises of public gathering places." beautifully evocative verbal description of the soundscape of late medieval Bruges by means of an introduction to a more traditional book on musicology, while Niall Atkinson has taken a lead from the more anthropological bias of Alain Corbin in his explorations of the acoustic environment and bells as expressions of power and control in Renaissance Florence. Gretchen Peters has recently produced a comparative study of the soundscape of French cities that positions the work of the musicologist outside the ecclesiastical spaces of performance, and specifically engages with the city through a close examination of the profession of minstrels (jongleurs), of civic performance, and of "how the political history of a city has affected its musical practices." 8 These and other works firmly remind us that early modern cities, and their public spaces and streets, were places animated by sound, many of which bore significant social and political meanings.

Streets were noisy, and they were often also dirty and smelly, and so the sensory and public health aspects have also received some recent attention. Alain Corbin has noted how it is the nineteenth-century preoccupation with separating sewage and filth from the streets that established the understanding of paving as a means of separating users on the street from the odors beneath the earth in sewers; here again, as with lighting or the end of the theater of justice, modernity is heralded by a sanitization of the street environment. Smell (or stench), like sound, was not confined by

\footnotetext{
${ }^{6} \mathrm{E}$. Cohen, 294.

${ }^{7}$ Smith, 55-56.

${ }^{8}$ Peters, 6.
} 
walls of buildings, but permeated through them; as Jo Wheeler has shown for Venice, sixteenth-century zoning and street-hygiene legislation recognized the widespread benefits to decorum of marginalizing certain trades and activities away from central streets. In addition to human waste, the animal waste produced by growing numbers of coaches in many early modern cities, as Mark Jenner has discussed for London, must have affected the streets in ways that researchers have barely yet explored.

This is just one new research area emerging from an approach focused on a study of street life - here intersecting elite consumption and display with transportation studies and street design — where further study might yield interesting results. As noted above, the fertile spaces for new research arise in those interstitial locations or mediating figures that are the product of the vibrant life of streets. Thus, for example, further work on the physical and spatial nature of such places as taverns, pharmacies, and barber shops, as well as the social interactions they favored, would reward further research, as might work on more mundane sites, such as water fountains. More broadly, an interdisciplinary research stance that views the street as a unit for a broader spatial (in the Lefebvrian sense) understanding of the social and material culture of the early modern public realm would make it possible to extract new meaning from known settings and contexts.

Finally, what is street life? How can we find it in the early modern city? And what areas might reward further inquiry? From the review of approaches and materials described here, and as I argue in a forthcoming book, the street might be best understood as an ecosystem, with multiple factors influencing its form, the way it was used, and how it was perceived. As I have suggested, street life as an area of study specifically sets out to cross between the physical and the social fabric of the city and to reveal the nature and degree of interdependence of one upon the other. While the street might be used for ephemeral displays of hegemonic power, it was also a space of the everyday, and as such provides a rich context for research into overlooked people, places, and practices. By opening up such a vast stage of urban life for observation, street life risks being found everywhere and nowhere, slipping away as easily as market stalls are packed up at the end of a day's trading. The challenge of the study of street life is to capture such everyday, ephemeral practices and anchor them in the fabric of the social, political, and cultural history of the early modern cities of Europe.

UNIVERSITY OF EXETER 


\section{Bibliography}

Arlinghaus, Franz-Josef. "The Myth of Urban Unity: Religion and Social Performance in Late Medieval Braunschweig." In Cities, Texts and Social Networks, 400-1500: Experiences and Perceptions of Medieval Urban Space, ed. Caroline Goodson, Anne Elisabeth Lester, and Carol Symes, 215-32. Farnham, 2010.

Arnade, Peter J. Realms of Ritual: Burgundian Ceremony and Civic Life in Late Medieval Ghent. Ithaca, 1996.

Arnade, Peter, Martha C. Howell, and Walter Simons. "Fertile Spaces: The Productivity of Urban Space in Northern Europe." Lournal of Interdisciplinary History 32 (2002): 515-48.

Atkinson, Niall. "They Rang the Bells at the Wrong Time." Interview by David Rosenthal and Fabrizio Nevola. In Urban Communities in Early Modern Europe (1400-1700): A Research Review, ed. Fabrizio Nevola and David Rosenthal. 2011. www. earlymoderncommunities.org.

Ballon, Hilary. The Paris of Henri IV: Architecture and Urbanism. New York, 1991.

Bate, Jonathan, and Dora Thornton. Shakespeare: Staging the World. London, 2012.

Bell, Rudolph M. Street Life in Renaissance Rome: A Brief History with Documents. Boston, 2013.

Blumin, Stuart. The Encompassing City: Streetscapes in Early Modern Art and Culture. Manchester, 2008.

Brennan, Thomas Edward. Public Drinking in the Early Modern World: Voices from the Tavern, 1500-1800. 4 vols. London, 2011.

Brown, Judith C., and Robert C. Davis, eds. Gender and Society in Renaissance Italy. London, 1998.
Calabi, Donatella. The Market and the City: Square, Street and Architecture in Early Modern Europe. Trans. Marlene Klein. Aldershot, 2004.

Cavallo, Sandra, and David Gentilcore, eds. Spaces, Objects and Identities in Earlv Modern Italian Medicine. Malden, 2008.

Çelik, Yeynep, Diane Favro, and Richard Ingersoll, eds. Streets: Critical Perspectives on Public Space. Berkeley, 1994.

Clarke, Georgia, and Fabrizio Nevola, eds. "Experiences of the Street in Early Modern Italy." I Tatti Studies in the Italian Renaissance 16.1-2 (2013): 47-230.

Cohen, Elizabeth S. "To Pray, To Work, To Hear, To Speak: Women in Roman Streets c. 1600." Lournal of Early Modern History 12 (2008): 289-311.

Cohen, Thomas V. Love and Death in Renaissance Italy. Chicago, 2004.

Connors, Joseph. "Alliance and Enmity in Roman Baroque Urbanism.” Römisches Jabrbuch für Kunstgeschichte 25 (1989): 207-294.

Corbin, Alain. Les Cloches de la terre: paysage sonore et culture sensible dans les campagnes au XIXe siècle. Paris, 1994. Published in English as Village Bells: Sound and Meaning in the Nineteenth-Century French Countryside. Trans. Martin Thom. New York, 1998.

- The Foul and the Fragrant. Odour and the Social Imagination. Leamington Spa, 1996.

Cosgrove, Denis. "Landscape and Landschaft." German Historical Institute Bulletin 35 (2004): 57-71.

Cowan, Alexander, and Jill Steward, eds. The City and the Senses: Urban Culture Since 1500. Aldershot, 2006.

Davis, Robert C. The War of the Fists: Popular Culture and Public Violence 
in Late Renaissance Venice. New York, 1994.

de Certeau, Michel. The Practice of Everyday Life. Berkeley, 1984.

de Vivo, Filippo. Information and Communication in Venice: Rethinking Earlv Modern Politics. Oxford, 2007.

Dooley, Brendan M., ed. The Dissemination of News and the Emergence of Contemporaneity in Early Modern Europe. Farnham, 2010.

Dubbini, Enzo. Geography of the Gaze in Early Modern Europe. Trans. Lydia Cochrane. Chicago, 2002.

Easterling, Heather. Parsing the City: Jonson, Middleton, Dekker, and City Comedy's London as Language. New York, 2007.

Ekrich, A. Roger. At Day's Close: A History of Nighttime. London, 2005.

Favro, Diane. "Meaning and Experience: Urban History from Antiquity to the Early Modern Period." Lournal of the Society of Architectural Historians 58 (1999/2000): 364-73.

Flather, Amanda. Gender and Space in Early Modern England. Woodbridge, 2007.

Foucault, Michel. Discipline and Punish: The Birth of the Prison. New York, 1977.

Garrioch, David T. "Sounds of the City: The Soundscape of Early Modern European Towns." Urban History 30.1 (2003): 5-25.

Gennep, Arnold van. The Rites of Passage. London, 1960.

Ghirardo, Diane Yvonne. "The Topography of Prostitution in Renaissance Ferrara." Iournal of the Society of Architectural Historians 60 (2001): 402-31.

Gowing, Laura. "The Freedom of the Streets': Women and Social Space, 1560-1640.” In Londinopolis: Essays in the Cultural and Social History of Early Modern London, ed. Mark S. R. Jenner and Paul Griffiths, 130-53. Manchester, 2000.

Howard, Jean E. Theater of a Citv: The Places of London Comedv 1598-1642. Philadelphia, 2007.
Jenner, Mark. "Overground, Underground: Pollution and Place in Urban History." Lournal of Urban History (1997): 97-110.

- "Luxury, Circulation and Disorder: London Streets and Hackney Coaches c. 1640-c. 1740." In The Streets of London: From the Great Fire to the Great Stink, ed. T. Hitchcock and H. Shore, 40-53. London, 2003.

Jerram, Leif. Streetlife: The Untold Story of Europe's Twentieth Century. Oxford, 2011.

Koslofsky, Craig. Evening's Empire: A History of the Night in Earlv Modern Europe. Cambridge, 2011.

Kostof, Spiro. The City Assembled: The Elements of Urban Form through History. London, 1992.

Kümin, Beat A. Drinking Matters: Public Houses and Social Exchange in Early Modern Central Europe. Basingstoke, 2007.

-. "Introduction." Political Space in Pre-industrial Europe, ed. Beat Kümin, 5-18. Farnham, 2009.

Kümin, Beat A., and B. Ann Tlusty, eds. The World of the Tavern: Public Houses in Early Modern Europe. Aldershot, 2002.

Laitinen, Riitta, and Thomas V. Cohen, eds. Cultural History of Early Modern European Streets. Special Issue of Journal of Early Modern History 12 (2008).

Lecuppre Desjardin, Elodie. La ville des ceremonies. Essai sur la communication politique dans les anciens Pays-Bas bourguignons. Turnhout, 2004.

Lefebvre, Henri. The Production of Space. Oxford, 1991.

-Writings on Cities. Ed. and trans. Eleonor Kofman and Elizabeth Lebas. Oxford, 1996.

MacGregor, Neil. Shakespeare's Restless World. London, 2012.

Mardock, James D. Our Scene is London: Ben Jonson's City and the Space of the Author. New York, 2008. 
Mengel, David Charles. "From Venice to Jerusalem and Beyond: Milic of Kromeriz and the Topography of Prostitution in Fourteenth-Century Prague." Speculum 79 (2004): 40742.

Miller, Naomi. Mapping the City: The Language and Culture of Cartography in the Renaissance. London, 2003.

. "A Sense of Place: A Treatise on Prostitution in Seventeenth-Century Paris." In Repenser les limites: l'architecture à travers l'espace, le temps et les disciplines, Paris, 2008. www.inha.revues.org/566.

Milner, Steven. "Fanno bandire, notificare, et expressamente comandare': Town Criers and the Information Economy of Renaissance Florence." In I Tatti Studies in the Italian Renaissance 16.1-2 (2013): 107-52.

Muir, Edward. Civic Ritual in Renaissance Venice. Princeton, 1981.

- Ritual in Early Modern Europe. Cambridge, 1997.

- "The Idea of Community in Renaissance Italy." Renaissance Quarterly 55 (2002): 1-18.

Mulryne, J. Ronnie, Helen WatanabeO'Kelly, and Margaret Shewring, eds. Europa Triumphans: Court and Civic Festivals in Early Modern Europe. 2 vols. Aldershot, 2004.

Nevola, Fabrizio. "Surveillance and Control of the Street in Early Modern Italy." I Tatti Studies in the Italian Renaissance 16.1-2 (2013): 85-106.

Nevola, Fabrizio, and David Rosenthal. Urban Communities in Early Modern Europe (1400-1700): A Research Review. 2011. www.earlymoderncommunities. org.

Nussdorfer, Laurie. "The Politics of Space in Early Modern Rome." Memoirs of the American Academy in Rome 42 (1997): 161-86.

Peters, Gretchen. The Musical Sounds of Medieval French Cities: Plavers, Patrons, and Politics. Cambridge, 2012.
Pettegree, Andrew. "A Provincial News Community in Sixteenth-Century Europe." In Public Opinion and Changing Identities in the Early Modern Netherlands: Essays in Honour of Alastair Duke, ed. Judith Pollmann and Andrew Spicer, 33-48. Leiden, 2007.

Pollak, Martha. Turin, 1564-1680: Urban Design, Military Culture and the Creation of the Absolutist Capital. Chicago, 1991.

Rebecchini, Guido. "Rituals of Justice and the Construction of Space in Sixteenth-Century Rome." I Tatti Studies in the Italian Renaissance 16.1-2 (2013): 153-80.

Rexroth, Frank. Deviance and Power in Late Medieval London. Cambridge, 2007.

Río Barredo, María José del. Madrid, urbs regia: la capital ceremonial de la Monarquía Católica. Madrid, 2000.

Rospocher, Massimo, ed. Beyond the Public Sphere: Opinions, Publics, Spaces in Early Modern Europe. Bologna, 2012.

Rubin, Miri. Corpus Christi: The Eucharist in Late Medieval Culture. Cambridge, 1991.

Ruff, Julius R. Violence in Early Modern Europe. Cambridge, 2001.

Rykwert, Joseph. "The Street: The Use of Its History." In On Streets, ed. Stanford Anderson, 14-27. Cambridge, MA, 1978.

Salzberg, Rosa. “'Per le piaze \& sopra il ponte': Reconstructing the Geography of Popular Print in Early SixteenthCentury Venice." In Geographies of the Book, ed. Charles W. Withers and Miles Ogborn, 111-32. Farnham, 2010.

. "Selling Stories and Many Other Things In and Through the City: Peddling Print Sixteenth-Century Florence and Venice." Sixteenth Century Journal 42.3 (2011): 737-59.

Schafer, R. Murray. The Soundscape: Our Sonic Environment and the Tuning of the World. Rochester, VT, 1993. 
Originally published as The Tuning of the World. New York, 1977.

Shaw, James E., and Evelyn S. Welch. Making and Marketing Medicine in Renaissance Florence. Amsterdam, 2011.

Sluhovsky, Moshe. Patroness of Paris: Rituals of Devotion in Early Modern France. New York, 1997.

Smith, Bruce R. The Acoustic World of Early Modern England: Attending to the O-Factor. Chicago, 1999.

Strohm, Reinhard. Music in Late Medieval Bruges. Oxford, 1985.

Symes, Carol. A Common Stage: Theater and Public Life in Medieval Arras. Ithaca, 2007.

. "Out in the Open, in Arras: Sightlines, Soundscapes and the Shaping of a Medieval Public Sphere." In Cities, Texts and Social Networks, 400-1500: Experiences and Perceptions of Medieval Urban Space, ed. Caroline Goodson, Anne Elisabeth Lester, and Carol Symes, 279-302. Farnham, 2010.

Tafuri, Manfredo. "'Roma Instaurata.' Strategie urbane e politiche pontificie nella Roma del primo Cinquecento." In Raffaello architetto, ed. Christoph L. Frommel, Stefano Ray, and Manfredo Tafuri, 56-106. Milan, 1984.

Terpstra, Nicholas. "Theory into Practice: Executions, Comforting and Comforters in Renaissance Italy." In The Art of Executing Well: Rituals of Execution in Renaissance Italy, ed. Nicholas Terpstra, 118-58. Kirksville, 2008.

Tlusty, Ann. "Violence and Urban Identity: Communication Strategies Between Authorities and Citizens in the Adjudication of Fights." In Cultures of Communication from Reformation to Enlightenment: Constructing Publics in the Early Modern German Lands, ed. James van Horn Melton, 10-23. Aldershot, 2002.

Trexler, Richard. Public Life in Renaissance Florence. New York, 1980.

-. "Introduction." In Persons in Groups: Social Behavior as Identity Formation in Medieval and Renaissance Europe, ed. Richard Trexler, 3-16. Binghamton, 1985.

Turner, Victor. The Anthropology of Performance. New York, 1987.

Ullyot, Michael. "Digital Humanities Projects." Renaissance Quarterly 66.3 (2013) 937-947.

Verdi Webster, Susan. Art and Ritual in Golden-Age Spain: Sevillian Confraternities and the Processional Sculpture of Holy Week. Princeton, 1998.

Weigel, Sigrid. "On the 'Topographical Turn': Concepts of Space in Cultural Studies and Kulturwissenschaften." European Review 17 (2009): 187-201.

Welch, Evelyn S. Shopping in the Renaissance: Consumer Cultures in Italy, 1400-1600. New Haven, 2005.

Wheeler, Jo. "Stench in Sixteenth-Century Venice." In The City and the Senses: Urban Culture since 1500, ed. Alexander Cowan and Jill Steward, 25-38. Aldershot, 2006.

Wilson, Bronwen, and Paul E. Yachnin, eds. Making Publics in Early Modern Europe: People, Things, Forms of Knowledge. New York, 2010.

Zika, Charles. "Hosts, Processions and Pilgrimages: Controlling the Sacred in Fifteenth Century Germany." Past and Present 118 (1988): 25-64. 